\title{
Corrigendum: Necromys lasiurus: Lessons From a 38-Year Study in an Amazonian Savanna
}

\section{Clarissa Alves da Rosa ${ }^{1}$, Pedro Henrique Salomão Ganança ${ }^{2 *}$, Albertina Pimentel Lima ${ }^{1}$ and William Ernest Magnusson ${ }^{1}$}

${ }^{1}$ Coordenação de Biodiversidade, Instituto Nacional de Pesquisas da Amazônia, Manaus, Brazil, ${ }^{2}$ Programa de Pós Graduação em Ecologia, Instituto Nacional de Pesquisas da Amazônia, Manaus, Brazil

Keywords: long-term studies, population dynamics, Rodent ecology, savanna mice, Tropical savanna

\section{A Corrigendum on}

Necromys lasiurus: Lessons From a 38-Year Study in an Amazonian Savanna by da Rosa, C. A., Ganança, P. H. S., Lima, A. P., and Magnusson, W. E. (2021). Front. Ecol. Evol. 9:716384. doi: 10.3389/fevo.2021.716384

\section{OPEN ACCESS}

Approved by:

Frontiers Editorial Office,

Frontiers Media SA, Switzerland

*Correspondence:

Pedro Henrique Salomão Ganança

psalogan@hotmail.com

Specialty section:

This article was submitted to

Conservation and Restoration Ecology,

a section of the journal

Frontiers in Ecology and Evolution

Received: 19 September 2021

Accepted: 06 October 2021

Published: 26 October 2021

Citation:

da Rosa CA, Ganança PHS, Lima AP

and Magnusson WE (2021)

Corrigendum: Necromys lasiurus: Lessons From a 38-Year Study in an

Amazonian Savanna.

Front. Ecol. Evol. 9:779782.

doi: 10.3389/fevo.2021.779782
There is an error in the Funding statement. The correct Name of one of the Funders is ** Coordenação de Aperfeiçoamento de Pessoal de Nível Superior-Brazil (CAPES)-PROEX n. $0742 / 2020^{* *}$.

The correct Funding section is below:

"In the last 3 years the data collection was financed by PELD (LTER)-POPA through the Conselho Nacional de Desenvolvimento Científco e Tecnológico (CNPq), grant number 441443/2016-8. Over the 20 years, INPA PPI-PRJ-1223 financed travel for AL. CNPq grants 446208/2015-9, 401120/2016-3, and 401327/2012-4 financed field assistants and material throughout the study. This study was financed in part by the Coordenação de Aperfeiçoamento de Pessoal de Nível Superior_Brazil (CAPES) - PROEX n. 0742/2020, for PHSG (Ph.D. scholarship)."

An author name was incorrectly spelled as ${ }^{* *}$ Clarisa Alves Rosa**. The correct spelling is ${ }^{* *}$ Clarissa Alves da Rosa**.

The authors apologize for this error and state that this does not change the scientific conclusions of the article in any way. The original article has been updated.

Publisher's Note: All claims expressed in this article are solely those of the authors and do not necessarily represent those of their affiliated organizations, or those of the publisher, the editors and the reviewers. Any product that may be evaluated in this article, or claim that may be made by its manufacturer, is not guaranteed or endorsed by the publisher.

Copyright $\odot 2021$ da Rosa, Ganança, Lima and Magnusson. This is an open-access article distributed under the terms of the Creative Commons Attribution License (CC BY). The use, distribution or reproduction in other forums is permitted, provided the original author(s) and the copyright owner(s) are credited and that the original publication in this journal is cited, in accordance with accepted academic practice. No use, distribution or reproduction is permitted which does not comply with these terms. 